\title{
Strategi Coping Stress pada Ibu Hamil di Masa Pendemi Covid 19
}

\author{
Isnaeni Rofiqoch, Sawitri Dewi, Diah Atmarina Yuliani \\ Email: neni.rofiqoch@gmail.com \\ DIII Kebidanan, Fakultas Ilmu Kesehatan, Universitas Muhammadiyah Purwokerto, Indonesia
}

\begin{abstract}
Abstrak
Masa kehamilan adalah masa penentu kesejahteraan dan perkembangan janin didalam Rahim. Selama masa kehamilan banyak wanita yang mengalami perubahan psikologis, sehingga diperlukan metode untuk mengurangi permasalahan yang timbul selama proses kehamilan, cara inilah yang disebut dengan stretegi coping. Tujuan dari penelitian ini adalah untuk mengidentifikasi Strategi Coping Stress Pada Ibu Hamil di Masa Pandemi Covid 19 Di Wilayah Puskesmas Purwokerto Selatan Kabupaten Banyumas. Penelitian ini merupakan penelitian Kualitatif dengan pedekatan Fenomenologi. Metode pengambilan data pada penilitian ini dilakukan dengan wawancara mendalam (indepth interview), penelitian ini diharapkan dapat menggali informasi tentang masalah psikologis apasaja yang dihadapi oleh ibu hamil dan bagaimana cara mereka melakukan coping untuk menyelesaikan masalah yang dihadapi selama masa pandemi covid 19. Informan Utama dalam penelitian ini adalah ibu hamil, sedangkan informan pendukung adalah bidan dan anggota keluarga (suami, ibu atau saudara) sebagai triangulasi. Hasil dari penelitian ini strategi coping stress selama kehamilan sangat diperlukan untuk mengurangi masalah selama masa kehamilan. Strategi coping stress selama kehamilan di masa pandemic covid 19 ini dilakukan dengan mekanisme Emosional Focused Coping dan Problem Facus Coping. Meskipun mekanisme Emosional Focused Coping lebih dominan digunakan oleh ibu hamil karena ibu hamil merupakan seorang Wanita yang dimana wanita lebih mengutamakan perasaan dari pada logikanya.
\end{abstract}

Kata kunci: strategi coping stress; kehamilan; covid 19.

\begin{abstract}
Pregnancy is a time of determining the welfare and development of the fetus in the womb. During pregnancy many women experience psychological changes, so a method is needed to reduce the problems that arise during the pregnancy process, this method is called a coping strategy. The purpose of this study was to identify coping strategies for stress in pregnant women during the COVID-19 pandemic in the South Purwokerto Community Health Center, Banyumas Regency. This research is a qualitative research with a phenomenological approach. The data collection method in this research is carried out by in-depth interviews. This research is expected to be able to dig up information about what psychological problems are faced by pregnant women and how they solve the problems faced during the covid 19 pandemic. The main informant in the meantime is mother pregnant, supporting informants are midwives and family members (husband, mother or sibling) as triangulation. The results of this study stress coping strategies during pregnancy are needed to reduce problems during pregnancy. This strategy for coping with stress during pregnancy during the COVID-19 pandemic is carried out with the mechanism of Emotional Focused Coping and Problem Facus Coping. Although the Emotional Focused Coping mechanism is more dominantly used by pregnant women because pregnant women are women where women prioritize feelings over logic.
\end{abstract}

Keywords: stress coping strategies; pregnancy; covid 19. 


\section{Pendahuluan}

Masa kehamilan adalah masa penentu kesejahteraan dan perkembangan janin didalam Rahim ibu. Kesehatan ibu selama hamil sangat menentukan perilaku dan perkembangan anak setelah lahir. Pengaruh lingkungan baik dari internal maupun eksternal sangat berpengaruh penting terhadap perkembangan dan kepekaan otak anak. Keterkaitan faktor resiko pada ibu hamil sering didapatkan dari berbagai macam studi penelitian yang diantaranya pengaruh prenatal dengan perkembangan janin, kekurangan makanan, alkohol, merokok dan obatobatan selama kehamilan dapat menyebabkan persalinan premature dan berat badan lahir rendah. Faktor internal juga seperti peningkatan stress dapat mempengaruhi terhadap kejadian persalinan premature dan beratlahirrendah (1).

Selama masa kehamilan banyak wanita yang mengalami perubahan psikologis. Perubahan psikologi pada ibu hamil akan terjadi selama masa kehamilan, efek perubahan psikologis ini dapat mempengaruhi kehamilan, bayi dan perawatan anak, oleh karena itu diperlukan upaya pengembangan preventif, promotif dan kuratif sebagai langkah utama dalam memberikan asuhan kebidanan pada ibu hamil di masa pandemic Covid19(2).

Perubahan psikologis selama kehamilan umum terjadi pada ibu hamil, karena dimasa kehamilan mengalami banyak perubahan hormon yang berpengaruh terhadap perubahan emosional ibu hamil. Oleh karena itu ibu hami lmembutuhkan metode untuk mengatasi perubahan psikologis tersebut agar tidak mengganggu ibu selama kehamilan. Coping adalah segala bentuk perilaku atau tindakan yang dilakukan seseorang untuk mengurangi atau menghilangkan ketegangan guna menghilangkan kondisi yang membebani dan menimbulkan stress, oleh karena diperlukan strategi coping untuk mengurangi stress selama kehamilan(3)(1).

Sesuai dengan hasil penelitian yang menyatakan bahwa semakin tinggi ibu hamil menggunakan stretegi coping jenis emotion-facused coping maka akan semakin rendah stress kehamilan yang dialaminya, namun apabila semakin rendah ibu hamil menggunakan stretegi coping jenis emotion-facused coping maka semakin tinggi stress yang dialami. Hal ini terkait dengan cara ibu hamil tersebut dalam mengatasi segala permasalahan yang timbul selama proses kehamilan(4)(5).

Kabupaten Banyumas merupakan salah satu kabupaten dengan dampak penularan Covid 19 tertinggi di Jawa Tengah, di tambah dengan adanya RS Rujukan Covid 19 yang ada di daerah wilayah Purwokerto Kabupaten Banyumas. Puskesmas Purwokerto Selatan merupakan salah satu puskesmas yang berada di wilayah Kotatib Kabupaten Banyumas yang pada tahun 2020 kasus Corona 19 di Puskesmas ini menjadi salah satu yang tertinggi. Dalam status normal, kematianibu dan kematian neonatal di Indonesia masih menjadi tantangan besar. Indonesia saat ini sedang menghadapi bencana nasional non alam Covid 19 sehingga pelayanan terhadap maternal dan neonatal juga mengalami dampak baik secara akses maupunkualitas(6)(7).

Berdasarkan data diatas peneliti ingin melakukan penelitian tentang Strategi Coping Stres Pada Ibu Hamil 
Di Masa Pendemi Covid 19 Di Wilayah Puskesmas Purwokerto Selatan Kabupaten Banyumas, diharapkan dengan adanya penelitianinidapat di ketahui bagaimana ibu hamil menghadapi kehamilannya di masa pendemic Covid 19 ini.

\section{Metode Penelitian}

Metode dalam penelitian ini merupakan penelitian Kualitatif dengan pedekatan Fenomenologi. Metode pengambilan data pada penilitian ini dilakukan dengan wawancara mendalam (indepth interview), penelitian ini diharapkan dapat menggali informasi tentang masalah psikologis apasaja yang dihadapi oleh ibu hamil dan bagaimana cara mereka melakukan coping untuk menyelesaikan masalah yang dihadapi selama masa pandemi covid 19. Pedoman wawancara yang digunakan merupakan hasil pengembangan dari peneliti yang di buat berdasarkan hasil Literatur Rievew jurnal-jurnal tentang Strategi Coping Stres.

Informan kunci pada penelitian ini adalah ibu hamil di wilayah kerja Puskesmas Purwokerto Selatan dengan jumlah 5 informan. Informan akan dilakukan wawancara mendalam dan akan di tanya tentang bagaimana seorang ibu hamil dalam menyelesaikan masalah psikologis selama masa pandemic covid 19. Sedangkan Informan pendukung digunakan sebagai triangulasi data yang terdiri dari keluarga (suami, orang tua, atau saudara) dan bidan yang memberikan asuhan selama kehamilan.

Hasil wawancara dilakukan analisis dengan menggunakan multipe case yaitu data dianalisis secara mendalam untuk menggambarkan tema penelitian secara terperinci kemudian analisis menyilang antara data yang didapat dari informan dan dilakukan pemaknaan hasil wawancara.

\section{Hasil dan Pembahasan}

Karakteristik Responden

Tabel. 1 Karakteristik Responden

\begin{tabular}{ccccc}
\hline \multirow{2}{*}{ No } & \multirow{2}{*}{ Kode } & \multicolumn{3}{c}{ Kategori } \\
\cline { 3 - 5 } & & Umur & Pendidikan & Pekerjaan \\
\hline 1 & IU1 & 20 & SMA & IRT \\
2 & IU2 & 25 & SMU & IRT \\
3 & IU3 & 31 & SMU & IRT \\
4 & IU4 & 23 & SMK & Buruh \\
5 & IU5 & 23 & SMA & IRT \\
6 & BD & 42 & D3 Bidan & PNS/Bidan \\
7 & PS1 & 35 & Doordinator & Wiraswasta \\
8 & PS2 & 47 & SMP & IRT \\
\hline
\end{tabular}

Berdasarkan hasil karateristik pada tabel diatas didapatkan informan sebanyak 8 orang terdiri dari 5 informan utama dan 3 informan pendukung. Informan utama merupakan ibu hamil yang berusia sekitar 20 - 35 tahun, berlatar belakang pendidikan SMU/SMK, dengan pekerjaan sebagai besar IRT dan ada 1 informan bekerja sebagai Buruh. Informan pendukung terdiri dari 1 bidan koordinator yang berusia 42 dan berlatarbelakang pendidikan D3 Kebidanan dan 2 Pendamping pasien dengan latarbelakang usia 35 dan 47, Pendidikan terakhir SMP dan Diploma 3, dengan pekerjaan Wiraswasta dan IRT.

Penelitian ini dilakukan di puskesmas Purwokerto Selatan Kabupaten Banyumas dengan jumlah Informan Utama (IU) sebanyak 5 Orang dan Informan Pendukung 
sebanyak 3 Orang yang terdiri dari 1 Bidan/Bidan Koordinator, 2 Orang dari pendamping informan utama. Selain data karakteristik didapatkan pula data maternal informan utama yaitu Usia Kehamilan informan direntang 34-39 minggu, sedangkan untuk gravida 4 informan status gravida 1 (satu), dan 1 informan memiliki status gravida 2 (dua), dan untuk status Abortus seluruh informan memiliki status Abortus belum pernah Abortus.

Berdasarkan hasil penelitian melalui wawancara mendalam diperoleh data tentang Strategi Coping Stress pada ibu hamil bahwa selama kehamilan di masa pandemic Covid 19 ibu hamil atauinforman utama melakukan kegiatan kegiatan yang tanpa disadari merupakan strategi coping stress dalam menghadapi pandemic Covid 19 di masa kehamilan. Adapun mekanisme Strategi coping stress yang dilakukan oleh para informan adalah Emosional Focused Coping yang merupakan cara mengatasi stress dengan mengelola emosi individu dan Problem Facus Coping merupakan cara mengatasi stress dengan mengelola masalah yang ada(3).

Hasil penelitian menunjukan bahwa Strategi Coping Stress melalui Emosional Facused Coping lebih mendominasi hal ini dapat terlihat dari kutipan wawancara dengan informan yang menyatakan :

"kalau masalah tertular covid saya pasrah aja sama yang diatas, karenakan corona itu pemberian dari yang di Atas (Tuhan)." (IU3)

"Takut sudahpastiya... kalo masalah hamil ya sudah biasa. Pasrah aja....." (IU1)

Berdasarkan pernyataan di atas dapat terlihat bahwa informan dalam mengatasi strategi coping stressnya dengan menggunakan metode Positive reappraisal (memberi penilaian positif) yaitu bereaksi yang menciptakan makna positif yang bertujuan untuk mengembangkan diri termasuk melibatkan diri dalamhalhal yang religious. Hal ini sesuai juga dengan penelitian dari Puente (2013) yang menyatakan bahwa Strategi Coping melalui Agama atau Religi dapat mempengaruhi seseorang untuk mengurangi kecemasan(8).

Strategi coping lain yang dilakukan oleh informan dalam menghadapi kehamilan dimasa pandemic covid 19 dengan Accepting responsibility (penekanan pada tenggung jawab) dan yaitu bereaksi dengan menumbuhkan kesadaranakan peran diri dalam permasalahan yang dihadapi, dan berusaha mendudukkan segala sesuatu sebagaimana mestinya. Berikut kutipan hasil wawancara dengan informan utama:

"takut ya mba.....makanya kmren di rumah terus. gak pernah keluar rumah..."(IU2)

"...hmm kurangi keluar rumah aja mba.....Menghindari kerumunan" (IU4)

Kutipan wawancara diatas menunjukan bahwa informan berfikir bahwa akan lebih aman jika tetap tinggal di rumah, sebagai rasa tanggung jawabnya sebagai ibu hamil yang harus menjaga diri dan janin yang ada di dalam kandungan. Berdiam diri di rumah juga merupakan salah satu cara untuk menghindari diri dari Virus Coorona. Hal ini juga sesuaidengan penelitian dari Moyer (2020) yang menyatakan bahwa ibu hamil untuk mengurangi kecemasan mereka lebih memilih untuk berdiam diri di rumah, dan melakukan pemeriksaan kehamilan 
mereka memilih untuk melakukannya dengan melakukan panggilan Video ataupun Telephone untuk perawatan prenatal selama masa pandemic Covid 19 (9).

Berdasarkan hasil kutipan wawancara dengan informan menunjukan bahwa ibu hamil selama masa pandemic covid 19 malakukan Strategi coping Stress dengan cara Self controlling (pengendalian diri) yaitu bereaksi dengan melakukan regulasi baik dalam perasaan maupun Tindakan. Sesuai dengan hasil wawancara dibawah ini:

"pas awal-awal takut ya mba.... Tapi lama-lama kesini sudah nggak, biasa aja......." (IU4)

Selain hasil kutipan wawancara diatas ibu hamil juga melakukan strategi coping stress dengan metode Distancing (menjaga jarak) agar tidak terbelenggu oleh permasalahan. Hal ini sesuai dengan kutipan wawancara di bawah ini:

".....nggak ngapa2in.... Takut ketularan, karena lagi hamil juga" (IU2)

Kedua strategi coping stress tersebut merupakan metode untuk menghindarikan diri dari masalah. Metode ini sering digunakan untuk mengurangi stress karena terlalu banyaknya masalah yang dihadapi. Sesuai dengan hasil penelitian yang menyatakan bahwa semakin tinggi ibu hamil menggunakan stretegi coping jenis emotion-facused coping maka akan semakin rendah stress kehamilan yang dialaminya, namun apabila semakin rendah ibu hamil menggunakan stretegi coping jenis emotion-facused coping makas emakin tinggi stress yang dialami(5).

Berdasarkan hasil wawancara yang dilakukan terhadap informan dalam penelitian ini juga didapatkan hasil strategi coping ibu hamil dalam menghadapi pandemic covid 19 ini dengan menggunakan metode Problem Facus Coping. Hal ini sesuai dengan kutipan wawancara di bawah ini:

“....sukanya mainan $H P$, nonton $T V$ di rumah.... "

"....iya membantu untuk menghilangkan rasa cemas dan tidak focus ke masalah-masalah yang sedang di hadapai..." (IU2)

Kutipan wawancara diatas menunjukan bahwa informan dalam mengatasi masalah dengan cara Planful Problem Solving yaitu bereaksi dengan melakukan usahausaha tertentu yang bertujuan untuk mengubah keadaan, diikuti pendekatan analitis dalam menyelesaikan masalah. Selain itu strategi coping yang lain yaitu dengan cara Seeking social support yaitu bereaksi dengan mencari dukungan dan pihak luar, baik berupa informasi, bantuan nyata, maupun dukungan emosional. Berikut kutipan wawancara dengan informan utama:

"Saudara, ibu.... Mereka memberikan saran agar tiidak terlalu cemas, jangan teralu di pikirkan takutnya malahan kenapa 2 katanya...." (IUI)

Berdasarkan hasil wawancara diatas menunjukan bahwa strategi coping stress yang dilakukan oleh ibu hamil dilakukan dengan metode Problem Facus Coping merupakan cara mengatasi stress dengan mengelola masalah yang ada. Hal ini sesuai dengan hasil penelitian dari Denise (2007) yang menyatakan bahwa Problem Facus Coping lebih banyak digunakan untuk menyelesaikan masalah dibandingkan dengan Emosional Focused Coping hal ini karena kecemasan akan hilang 
seiring berjalannya waktu kehamilan(10).

Berdasarkan hasil penelitian ini menunjukan bahwa informan utama melakukan strategi coping selama kehamilan di masa pandemic covid 19 ini dilakukan dengan dua metode yaitu Emosional Focused Coping dan Problem Facus Coping. Meskipun strategi yang paling dominan digunakan adalah bentuk Emosional Focused Coping karena Wanita terutama ibu hamil lebih mengutamakan perasaan daripada logikanya. Sesuai dengan hasil penelitian Rahmatika (2014) yang menyatakan bahwa semakin tinggi ibu hamil menggunakan stretegi coping jenis emotion-facused coping maka akan semakin rendah stress kehamilan yang dialaminya, namun apabila semakin rendah ibu hamil menggunakan stretegi coping jenis emotion-facused coping maka semakin tinggi stress yang dialami(5).

\section{Kesimpulan}

Berdasarkan hasil penelitian yang telah dilakukan oleh peneliti menunjukan bahwa informan utama melakukan strategi coping selama kehamilan di masa pandemic covid 19 ini dilakukan dengan mekanisme coping yang berpusat pada emosiatau Emosional Focus Coping dengan metode Positive reappraisal (memberi penilaian positif), Accepting responsibility (penekanan pada tenggungjawab) Self controlling (pengendalian diri) dan Distancing (menjagajarak). Selain itu Mekanisme coping yang berpusat pada masalah atau Problem Facus Coping juga dilakukan oleh ibu hamil untuk melakukan strategi coping stress disaat pandemic Covid 19 dengan metode Planful Problem Solving Seeking social support.

\section{Daftar Pustaka}

[1] A. C. Huizink, P. G. Robles de Medina, E. J. H. Mulder, G. H. A. Visser, and J. K. Buitelaar, "Coping in normal pregnancy," Ann. Behav. Med., 2002, doi: 10.1207/S15324796ABM2402_1 0.

[2] Purwaningsih H., "Analisis Masalah Psikologis pada Ibu Hamil Selama Masa Pandemi Covid-19 : Literature Review," $J$. Psikol., pp. 9-15, 2020.

[3] S. Maryam, "Strategi Coping," $J$. Konseling Andi Matappa, vol. 1, no. 2, p. 101, 2017.

[4] C. M. Guardino and C. Dunkel Schetter, "Coping during pregnancy: a systematic review and recommendations," Health Psychol. Rev., vol. 8, no. 1, pp. 70-94, 2014, doi: 10.1080/17437199.2012.752659.

[5] R. Rahmatika, "Hubungan antara emotion-focused coping dan stres kehamilan," J. Psikogenes., vol. 3 (1), no. 1, pp. 92-103, 2014.

[6] Direktorat Kesehatan Keluarga, "Pedoman Bagi Ibu Hamil, Ibu Nifas, dan Bayi Baru Lahir Di Era Pandemi Covid-19," pp. 912, 2020.

[7] Dinkes Banyumas, "Profil Kesehatan 2019," J. Chem. Inf. Model., vol. 53, no. 9, pp. 16891699, 2020.

[8] C. Peñacoba-Puente, F. J. Carmona-Monge, D. MarínMorales, and K. Naber, "Coping strategies of Spanish pregnant women and their impact on anxiety and depression," Res. Nurs. Heal., 2013, doi: 10.1002/nur.21513. 
[9] C. A. Moyer, S. D. Compton, E. Kaselitz, and M. Muzik, "Pregnancy-related anxiety during COVID-19: a nationwide survey of 2740 pregnant women," Arch. Womens. Ment. Health, vol. 23, no. 6, pp. $757-$ 765, Dec. 2020, doi: 10.1007/s00737-020-01073-5.

[10] D. Côté-Arsenault, "Threat appraisal, coping, and emotions across pregnancy subsequent to perinatal loss," Nurs. Res., 2007, doi:

10.1097/01.NNR.0000263970.08 878.87 . 